\title{
THE DETECTION OF A CASE OF SIMULATION OF
}

\section{INSANITY BY MEANS OF ASSOCIATION TESTS}

BY EDWIN W. KATZEN-ELLENBOGEN, M.D.

\section{Late Assistant Physician, Danvers State Hospital, Lecturer of Abnormal Psychology, Harvard University (1909-1910)}

$\mathrm{I}$

$T$ is a dangerous enterprise to prematurely apply theoretical findings of any science to practical use, as the frequent failures which result therefrom not only discourage the workers, but also cast discredit upon the work itself.

Psychology, because of its extreme youth as a science, is in a somewhat perplexing situation just at the present time. Its extensive development during the last few decades--it was at the recent date of 1875 that Wundt's Psychological Laboratory in Leipsic was opened - renders it most difficult for even a specialist in this science to become familiar with contemporary psychological research work in its entirety.

The use of the term child prodigy, because of this apparent precocity, may therefore not be considered misapplied. One cannot indeed overlook the marked similarity with its implied dangers existing between psychology in its present state and those musical wonders who, pushed before the public because of their fascinating powers "to charm, are forced thereby to neglect their studies and opportunities for serious development, thus after a few years carrying with them their stunted growth into the oblivion of unfulfilled expectations and general disregard.

In answer to the demands for proofs and demonstrations of the growth of psychology, from those standing in friendly as well as antagonistic relations to this science, there have appeared during the past few years books and articles proving the fact that psychology in the past thirty-five years has reached a point of development which it has taken centuries for other sciences - physics, for instance, to attain. 
However, in spite of the fact that we are prepared to utilize our theoretical experiences and put to the test their practical usefulness; in spite of the fact that a few psychological findings have already demonstrated their intrinsic value along these lines, the apparent success with which these methods have been taken from the hands of skilful psychologists and adapted to various uses and purposes by physicians, teachers, and social workers, has been too general to inspire confidence in the durability and permanence of this success.

The eventuality, therefore, of a reaction, with its accompanying logical criticism, both embarrassing and disappointing to the enthusiast, is not to be lost sight of. Wilhelm Wundt himself, the father of our modern experimental psychology, warns us of the dangers arising from this utilization of psychology for its own practical purposes, and in a recent article* in which he speaks of Meumann's Applied Psychology in Pedagogics, he protests against the abuse of psychologic tests, the value of which have not as yet been clearly and definitely settled upon.

Association tests are the most popular form of tests among all practical psychologists, and there is no doubt but that their skilful and critical use is of eminent value for the physician, teacher, and social worker.

In this article I wish to introduce a case in which the association test was the means of the verification of my suspicions of a simulation of insanity by a criminal.

${ }^{*}$ Wilhelm Wundt, Psychologische Studien, v. 5, 1910. Uber reine und angewandte Psychologie. On page 47, concluding the criticism of Meumann's applied psychology in pedagogics, he says, literally, " . . . . Wenn ein Forscher, der, wie Meumann, in frueheren Arbeiten glaenzende Proben seiner Bafæhigung fuer die Analyse psychologischer Einzelprobleme abgelegt hat, durch eine længere, vielleicht allein ausschliessliche Beschaeftigung mit Lernmethoden und xhnlichen praktischen Aufgaben, auf solche bedenkliche Wege geraten ist, was soll man aber dann erst von den experimentellen Pædagogen erwarten, die ohne diese Vorbereitung, der Fuehrerschaft der von der Psychologie heruebergekommen Padagogen folgend, Erziehung und Unterricht reformieren wollen? Wiederum kann man ihnen nur raten, zunaechst und vor-allen allseitig gebildete, nicht einseitig orientierte Psychologen zu werden und dann an die Frage hinanzutreten, wie von dem so gewonnenen Standpunkte aus auch der Pragogik neue Aufgaben zu stellen seien." 
My polemic against the abuse of psychology was intended for the numerous skeptics as a proof that I am not only aware of the difficulties associated with the application of laboratory tests to practical use, but also of the dangers which result from the drawing of false conclusions.

I also wish to prove by the publishing of this article the incontestability of the practical use of the association test with proper and objective application, the success indeed resulting therefrom having already in many instances been proven beyond a reasonable doubt.

In the fall of 1909 there was admitted to the Danvers State Hospital a young man of twenty-one, F. B., who, according to the physician's certificate (I must remark that the committing physicians were skilful psychiatrists), was an epileptic, who had had on several occasions periods of amnesia, and who, apparently in an epileptic twilight condition aggravated by alcoholic excesses, had committed a highway robbery.

The history given by the father did not convince me of an epileptic condition, although his story in no way disproved the possibility of such a condition. No hereditary history was given.

On admission the patient was clear, good natured, emphasizing the fact that he had absolutely no recollection of what had led to his arrest, admitting only alcoholic excesses and the knowledge of his having committed assault and battery on an old man, at the same time stating that this knowledge had been acquired when the police officer had arrested him. His story seemed to be probable, and he did not contradict himself to any remarkable extent in the following few weeks of observation.

I can give no definite reason for my doubts that the patient's amnesia was other than genuine, except that I suspected in him a tendency to fabulation. The association tests made at the time did not prove anything significant, as I was not in possession of the facts or circumstances under which the crime had been committed. My first report, therefore, to the district attorney bore the statement of my inability to form an opinion at the time stated, regarding the prisoner's sanity. 
The case was put on file.

Two months after the commitment, the patient's conduct meanwhile in the hospital having becn exemplary, with no occurrence of any epileptic manifestations, I finally was able to obtain an account of the circumstances under which the crime had been committed. The youth, it seemed, had entered a grocery store belonging to an old man in $\mathrm{Gr}$, in a somewhat intoxicated condition, giving to the grocer as an excuse that he had come to warm himself near the fire. It was nearly eight o'clock in the evening and, the grocer having closed his store for the night, the young man insisted on accompanying him, in spite of the grocer's protests, and together they walked some distance along the street. In a deserted part of the town, where there were few passersby, the young man suddenly knocked down the grocer and demanded money. The assaulted man receiving no assistance to his cries for help, the young man was given the sum of two dollars and departed from the place, leaving the grocer to his fate.

The old man's wound proved to be of minor severity, but as he was of the advanced age of eighty years and had lost much blood, he was quite sick as a result for some time. After the assault, the patient went to a saloon where a couple of hours later he was arrested.

Having now become acquainted with the facts I constructed a series of words dealing with the circumstances of the assault and inserted between them various indifferent words of no import or allusion to the crime.

\section{Association Test*}

\begin{tabular}{lcccc} 
Test Word & Time in Seconds & $\begin{array}{c}\text { Association } \\
\text { Word }\end{array}$ & \multicolumn{2}{c}{10 Reproduction } \\
hinutes & later \\
house & 3 seconds & grass & 4 seconds & water \\
table & 3 " & chair & 2 " & chair \\
room & 5 " & suite & 3 " & yes \\
watch & $2 \frac{1}{2}$ " & time & 2 " & time
\end{tabular}

*In order to make the test more transparent I have omitted many insignificant words which are indicated by the number of dashes inserted between the test words. His normal time of reaction in former tests was between two and a half and three seconds. Association test words were repeated ten minutes later and are recorded under "reproduction." Time was recorded with a stop watch. 


\begin{tabular}{|c|c|c|c|c|c|c|}
\hline Test Word & \multicolumn{3}{|c|}{$\begin{array}{c}\text { Time in Seconds Association } \\
\text { Word }\end{array}$} & \multicolumn{3}{|c|}{$\begin{array}{l}\text { Reproduction } \\
10 \text { minutes later }\end{array}$} \\
\hline police & & conds & "Billy" & 3 & seconds & badge \\
\hline father & 3 & $\$$ & love & 2 & " & mother \\
\hline grocery & 6 & $"$ & You said grocery? fire & 8 & “ & time \\
\hline old man & 5 & " & youth & 4 & “ & father \\
\hline murder & 2 & “6 & help & 9 & “ & no $\operatorname{sir}$ \\
\hline liquor & 3 & “ & fire & 4 & "6 & bad \\
\hline memory & 22 & “ & house & 3 & 4 & yes sir \\
\hline robber & 3 & 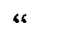 & thief & 3 & “ & thief \\
\hline dollar bill & 4 & “ & silver & 2 & “ & memory \\
\hline imagination & 5 & “ & water & 5 & “ & no sir \\
\hline insane & 4 & $"$ & no sir & 1 & “ & no sir \\
\hline guilty & 2 & 6 & no sir & 4 & “ & no sir \\
\hline prison & 5 & “ & no & 3 & " & yes \\
\hline bed & 2 & “ & cloth & $2 \frac{1}{2}$ & “ & cloth \\
\hline mother & 2 & 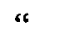 & father & 2 & 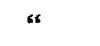 & father \\
\hline Reagan & 2 & “6 & Thomas & 4 & “ & storekeeper \\
\hline King street & 1 & $"$ & yes sir & 11 & “ & Gr.(name of place) \\
\hline left pocket & 4 & “ & clothes & 2 & “ & clothes \\
\hline money & 2 & $" s$ & bills & 3 & “ & paper \\
\hline left temple & 4 & “ & left temple? brain & 8 & “ & bottle (?) \\
\hline blow & 3 & s" & with the right hand & 2 & “ & no sir \\
\hline false & 14 & “ & time & 2 & “ & hope \\
\hline horse & 1 & “ & harness & 3 & “ & wagon \\
\hline God & 2 & " & Jesus & 5 & “ & $\operatorname{man}$ \\
\hline punishiment & 1 & $"$ & yes sir & 4 & “ & yes sir \\
\hline
\end{tabular}

\section{Discussion of the Test}

The first six words were of indifferent character and were within the limit of normal association time. The first test word having some connection with the crime was the word "grocery." The time of association was immediately doubled and the association words were "you said grocery? - fire."* The association for the test words "old man" was somewhat retarded - five seconds - and was insignificant. The next five indifferent words showed

*I have often remarked that in test words having some emotional value, the word is repeated in a questioning manner, as though it had not been heard correctly. 
the normal association time of three seconds. To the next test word "murder," the time of association was shorter than his usual time of reaction, and the word "help" was given with a sharp intonation, as though he were in reality calling for help. To the word "liquor" the association time was normal, the association word being "fire." To the word "memory," after twenty-two seconds, he answered "house."* Four indifferent words followed with a somewhat increased time reaction. To the test words "robber" and "dollar bill" the time was fairly normal and the association words insignificant. To the test word "imagination" after five seconds, he gave the association word "water." The association to "insane" and "guilty" was "no sir." In the first instance the time required was four seconds, and in the second instance two seconds. To the word "prison" up to five seconds he gave the association word "no." To a few insignificant words the association time was now somewhat prolonged, approaching four seconds (in appearance the patient was somewhat excited, his face being rather flushed). To the name of the assailed man the association time was two seconds and the association word was the man's Christian name. To the sharply spoken name of the street where the assault happened, the association time was extremely short, for him, being hardly one second, "yes sir." The four indifferent words following showed an increased time, between four and five seconds, otherwise insignificant in their association. To the words "left temple," after four seconds, "left temple? - brain." Six insignificant words followed. To the word "blow" after three seconds, "with the right hand." To the word "fake," after fourteen seconds, "time."

After ten minutes I repeated the same test words, having in the mean time made no reference whatever in our conversation to my suspicions regarding his simulation. I must add, however, that a few weeks previous I had mentioned to him the possibility of his simulation, to which he had replied with great indignation in the negative. During this ten minutes' time the patient smiled often, seemed to be thinking hard and acted as though he were

"The first word in the association test. 
feeling quite uncomfortable, without, however, making any comments. To the first test word given him, "grocery," he reacted after eight seconds, with the word "time." To the word "murder," up to nine seconds, "no sir." To the word "memory," after three seconds, again, "Yes sir." To "dollar bill," after two seconds, "memory." To "King Street," after eleven seconds, "Gr_—" (name of the town). To "left temple," after eight seconds, "bottle." To "blow," after two seconds, the words "no sir."

Studying this association test, I constructed from these words a plausible hypothesis of the patient's process of thought during the experiment. At the beginning of the experiment he was free from any suspicion or anxiety, for it had been tried on him before, and on other patients, as a matter of routine, and the attitude he took was one rather of amusement. When the first word was given, which was of significance to him (the word "grocery"), he started and repeated the word as though he had not clearly understood, the real association word being "fire." This first association was evidently suffcient to arouse his suspicions to such a degree that his thoughts were directed as $I$ intended them to be, along the course of events relating to the adventure in question, this being shown by the fact of his having mentioned to $\mathrm{Mr}$. $R$., upon entering the grocery, that he had come to warm himself near the fire. Nevertheless, in spite of this, he apparently decided that the word was purely accidental, having at the same time without doubt a definite review of the scene which had taken place at the time of responding. In this way, when the word "murder" was given he unconsciously and very quickly responded with the "help" in a realistic tone of voice, which undoubtedly was a reminiscence of the cry for help uttered by the old man. The idea then presented itself to him that this association test might be of more importance and more compromising than was desirable, and not simply, as he had previously thought, a matter for amusement or of routine. When the word "memory" was given, therefore, he was greatly embarrassed how to answer, and for twenty-two seconds he tried to figure out an innocent answer, finally choosing the first best word 
which entered his mind and which happened to be the first test word that had been given him in the experiment. To a few indifferent test words following, the associations were insignificant, the time of reaction, however, prolonged, which simply proved that he had not entirely recovered from the shock. To the words "insane," "guilty," "prison," he responded with "no sir." These associations proved that he had begun to attach a grave importance to the test, and responded as though they were questions directed to him. Upon the name of the assaulted man being given him he undoubtedly became convinced that the test was a kind of investigation, and becoming alarmed, realizing the whole danger, the scene of the assault presented itself in such a vivid manner to him that when the next word was given the name of the street where he had committed the assault he involuntarily answered the truth with "yes sir." As he had previously claimed that he did not even know in which of the neighboring towns he had committed the crime, this reaction, as well as that to the next test word, in which he reveals the truth, in spite of his better sense and wish, being forced to respond in a way contrary to that which he intended, is in accordance with the well-known explanation of Freud's "Sich-Versprechen" (slip of the tongue).*

His excitement and embarrassment now increasing, to the test word "blow" he finally reacted with a description of the manner in which he had inflicted it "with the right hand." During the ten minutes following he had time to think over the danger which his associations were likely to entail upon him and tried to correct himself, when the same test words were given again, which very thing, however, proved to be a still more convincing indictment. This time to the word "grocery" in the reproduction he associated the word "time." To the test word "murder," after nine seconds, "no sir." To the test word "memory," he responded, "yes sir" (Freud's Paradox Reaction cited above). To "King Street," after eleven seconds, he gave the name of the town where King Street is. To "left temple," after

*See Freud's Pathologie des Alltagslebens; quite an interesting example in literature would be the Sich-Versprechen of Mime in Wagner's Siegfried, while inducing the young Siegfried to kill Fafner. 
eight seconds, the word "bottle."* To the word "blow," "no sir," and to the word "fake," after two seconds, "hope," which latter word would indicate quite a reasonable suggestion that he hoped his faking would be successful.

\section{Conclusions}

This experiment proved to me the facts beyond any possible doubt that, not only did the man show no sign of being afflicted with any form of amnesia whatsoever, but also that his degree of intoxication at the time of the assault was far from being severe, as he had a more precise recollection of his actions than even a moderately intoxicated man would have had.

The description of his condition, that is the degree of his intoxication when found by the police, was such as would render him under continental law irresponșible for the commitment of the crime - in Austria, for instance, he would have been punished merely for the fact of his being intoxicated - his mental condition falling under the head of "clouded consciousness," which eliminates all legal responsibility.

My conclusion drawn from his behavior under the test was that he had reached this degree of intoxication after the crime. For a week I mentioned nothing of importance regarding this experiment to him and he avoided any reference to the test. Then taking him aside for a private conversation, I said, "John, you remember the experiment we had a week ago? It proved to me without doubt that you are not insane, that you never were insane, and that you are only pretending not to remember anything that has happened." I carefully avoided making any reference to any details of the crime.t "I shall make a report to

*At'that time I considered the association word as an accidental one, his confession, however, proved that in his embarrassment over what to answer the association proved to be very pertinent, the blow having been struck with a full bottle of whiskey which he had in his possession, a fact unknown to the police, but revealed by the patient himself in his confession.

$\dagger$ Professor Münsterberg, to whom I mentioned this experiment, raised the possible objection that even this test would not necessarily prove that his amnesia was not genuine. It might be possible, Professor Münsterberg suggested, that the 
the district attorney to this effect, and although it is of no importance to me what you do, I nevertheless sincerely advise you to give up faking, as it will make a very bad impression on the court, and it will only be to your advantage to make a clear confession."

The patient did not reply for about two minutes. I waited. Then he asked me, "In what way would it help me?" I answered, "I cannot tell you exactly, but I think that it would shorten your sentence." "Then, doctor," he said, "I admit I faked from the beginning." He then told me the whole story, with minute details, even drawing for me a plan of the street where it happened, showing the places which he had selected for the crime, as he confessed that he had entered the store with the idea of committing assault, and giving as the reason for his change of plan that he had thought there were people passing in the street. A description was also given of the blow which he had inflicted, correcting the statement of the assaulted man regarding the amount of money received, stating that he had asked for only two dollars and had received four. $\mathrm{He}$ now seemed most anxious to give an exact account of the

test words themselves had brought back a remembrance of the occurrence in a suggestive way. This objection is an exceedingly proper one, as it shows that even when in possession of as clear a case as the one we have at hand, with apparently unmistakable proofs, one should be most careful in the interpretation of the findings before the proper conclusion may be drawn. The exception thus grounded would be very grave, were it not for the subsequent confession, and had I not taken the precaution immediately after the experiment, to refrain from mentioning any of the items in the findings and from referring to any of the details of that which had taken place: nor did I omit taking these precautions even a week later; I merely stated, both these times, the conclusions which I had drawn from the test.

Experience shows us that a sudden return of memory in epileptics is just as likely to occur as a sudden loss of the same. Epileptics in court, for instance, often confess something which they have previously denied for some length of time, the next day again persisting in their denial, this at the same time being perfectly genuine. As can be seen, these reminiscences do not "stick." The analogy to this transitory clear memory we have in our dreams; in the morning we can remember them quite well and are capable of reviewing them, although a couple of hours later we may have no remembrance of having gone through this process, in spite of the fact that it had apparently taken place in a perfectly wakened state of mind. (Compare Kræpelin's statement on this subject in the Psychiatrie.) 
assault" and finished his confession with the remark, "Well, I thought I was smart, but there are smarter ones than me. When you tried that test on me I thought that I had given myself up, but hoped [compare association word "hope" with the test word "fake"] that you would not notice it. I never supposed that from single words I said you could find me out. Now, doctor, be good to me and try to help me in court."

I made my report to the district attorney and the case came on trial soon after in the Superior Court in Salem. The patient pleaded guilty, and I was called on the witness stand to give my opinion of the man. $U p$ to now the case had seemed to be quite clear, but at this point I began to have scruples, as I didn't feel justified in saying that the man was fully responsible for his actions. One could not call him feebleminded in the ordinary sense of the word, as his skilful and in a way successful simulation showed a fairly decent amount of self-control and mental competence. At the same time he was in a way of a low grade of mentality, a good-natured giant (the man stands six feet three inches in stockings) who would have harmed no one, it seemed to me, had he not been weakened by some outside influence which in this case was alcohol. I did not consider him of the class of brutal highway robbers, as he had attempted no disguise, and his apparent lack of consideration that the assaulted man would recognize and report him amply showed that we had to deal with an inferior individual under the influence of alcohol.

The question which now presented itself for me to decide was whether the man was insane or not. I was compelled to deny that he was afflicted with a psychosis, although the very fact of his simulation showed a certain strain of abnormality in his makeup. His degree of feeblemindedness was not sufficient to warrant exemption from punishment. While I fully recognize that under the influence of alcohol and bad society this man might prove to be an extremely

*A very well-known experience with criminals, that in the moment of confession it is done with apparent pleasure, and they incriminate themselves more than is necessary. They often indeed confess to crimes which it was not previously suspected they had committed. 
dangerous individual, his good nature, his tendency to being easily influenced, and his perfect conduct in the hospital, as he had shown himself a help to other patients, had not attempted to escape, and had shown himself to be a splendid and steady worker, all these facts led me to think that he might not be entirely lost, which would, therefore, not exclude the possibility of his living at large, after having been subjected to the influence of some favorable work of reformation.

The insane hospital was not the place for him, the conditions there, such as overcrowding, want of sufficient force of specialized physicians, etc., with no time to devote tothe work of reformation, would make this institution unavailable, his detention there being simply a custodial one. The prison would be absolutely detrimental in its influence, as he would there come in contact with obstinate criminals, and would no doubt as a result develop into one himself. Having frankly stated my doubts and objections to the judge, I was then asked whether I would not apply to the respondent the legal term of the German criminal code of "diminished responsibility,"* and I, answering in the affirmative, the judge having recognized the force of the stated doubts, the prisoner was sentenced to the one appropriate institution in the state, that is to the Concord Reformatory for an indefinite term.

This example proves that psychology, even in its present adolescent state, can be of assistance in problems of practical life, although it would be entirely wrong to contend that by the association test the truth of a person's statement could be positively determined. Indeed, if the association test were to be used for this purpose, I should prefer to refrain from the use of it altogether.

Some writers on this subject seem to entertain this dangerous delusion, which would lead to more miscarriage of justice and errors than one could possibly imagine. Our

*The modification of responsibility in the German criminal code has proved in reality to be more harmful than useful. A criminal of this type gets a shorter sentence and in this way, he being released from prison sooner, would earlier become a chronic danger to society. The only possible jurisdiction for the pleading of diminished responsibility would be an unlimited sentence in some reformatory, as happened in this particular case. 
psychic apparatus is too complicated to admit of its subjugation to such a mechanical law.*

I believe, however, that by skilful application to certain cases, the association test may prove a very valuable addition to many tests in criminal investigating work, as has been lately shown by the Bertillon methods, etc., and be of great assistance in many instances for clearing away doubts as to the truthfulness of witnesses.

In the case under review, I worked with a man wholly unprepared and incapable of understanding the purpose of the investigation, ignoring the facts that a hesitation, a change of word in the reproduction, were the very instances which would most convincingly cell against him. Considering even the circumstance of his knowing these facts, of his even being a psychologist quite skilful in psychological technique, he would be equally unable to control the form of his answers and the time of associations, even to a fraction of a second. The attempt to control his answers or prepare them beforehand would incriminate him more than anything else. In this same way a refusal to cooperate might be equally harmful as a result.

This argument in favor of the association test is rather directed to the sceptical students of law, as the psychologists themselves are more inclined towards an optimistic than a pessimistic view of the success of these tests. One cannot doubt the humaneness of this method of seeking for truth, as compared with the third degree system which is still in practice in Russia, and strange to say in some police stations in this free country of the United States. The criminal himself would scarcely object to this form of investigation, as it would rather impress him with the fact of his having been cleverly overtricked; to the very end both he and the examiner are able to remain on friendly terms, as it happened in the case which I have just reviewed. $\dagger$

*Cf. Münsterberg's, On the Witness Stand.

It was quite interesting to me to know how my patient had formed the idea of faking insanity: He told me-that it had not occurred to him until his examination by the com nitting physicians, and that it had then seemed to him that to be declared insane would be a rather nice way of getting out of his difficulty, inasmuch 
The case I have reported is in many ways a model case and one would probably not often find such an easy task as this one proved to be. Nevertheless, it can be said that the association test will almost always be of some help in advancing a criminal investigation.

as he would behave well in the hospital and would probably be released after a little while. This certainly would be easier for him than going to prison, in fact he had already heard about its being done and had read of it in the papers - for instance - the Thaw case.

The idea of faking amnesia presented itself to him through a leading question put by the examining physicians - a fact in no way reproachful to them, arising, as it did from the conscious effort on their part to make as complete an examination as possible. This incident, however, shows how dangerous, in many cases, a definite suggestive question may prove, putting a ready answer in the mouth of the witness. (Compare with Stearns's work on evidence.) Last, byt not least, I would call attention to the effect of newspapers containing reports of murders, etc., upon the minds of those criminally disposed. To illustrate this, consider, for instance, a clever book by Melville Davison Post, The Strange Schemes of Randolph Mason, which one might almost say contains a direct invitation to crime. It is not my desire to advocate censorship, but a restriction should certainly be placed upon the circulation of such dangerous types of literature. If the subject Mr. Post deals with had been introduced by him in the form of a serious work, it would have proven to be of very great value, whereas now, in its present form of a light novel, its harmful influence is immeasurably extensive. The only appreciable value of the book, indeed, is the comparative expense of the edition. Books of this kind should be excluded by law at least from public libraries. The author's intentions, no doubt, were all that could be desired, attempting to prove, as he did, the ineffectiveness of law against certain crimes, if skilfully prepared, and to his credit I wish to believe that he simply failed to realize the limitless dangers associated with his publication. 